\title{
Street homelessness in South Africa: A perspective from the Methodist Church of Southern Africa
}

\begin{tabular}{|c|c|}
\hline \multicolumn{2}{|c|}{$\begin{array}{l}\text { Authors: } \\
\text { Noah K. Tenai }{ }^{1} \text { (] } \\
\text { Gloria N. Mbewu' }\end{array}$} \\
\hline \multicolumn{2}{|c|}{$\begin{array}{l}\text { Affiliations: } \\
{ }^{1} \text { Unit for Reformational } \\
\text { Theology and the } \\
\text { Development of the South } \\
\text { African Society, Faculty of } \\
\text { Theology, North-West } \\
\text { University, Potchefstroom, } \\
\text { South Africa }\end{array}$} \\
\hline \multicolumn{2}{|c|}{$\begin{array}{l}{ }^{2} \text { Methodist Church, } \\
\text { Johannesburg, South Africa }\end{array}$} \\
\hline \multicolumn{2}{|c|}{$\begin{array}{l}\text { Corresponding author: } \\
\text { Noah Tenai, } \\
\text { ktenai@gmail.com }\end{array}$} \\
\hline \multicolumn{2}{|c|}{$\begin{array}{l}\text { Dates: } \\
\text { Received: } 29 \text { May } 2019 \\
\text { Accepted: } 28 \text { Oct. } 2019 \\
\text { Published: } 23 \text { Jan. } 2020\end{array}$} \\
\hline \multicolumn{2}{|c|}{$\begin{array}{l}\text { How to cite this article: } \\
\text { Tenai, N.K. \& Mbewu, G.N., } \\
\text { 2020, 'Street homelessness in } \\
\text { South Africa: A perspective } \\
\text { from the Methodist Church } \\
\text { of Southern Africa', HTS } \\
\text { Teologiese Studies/Theological } \\
\text { Studies 76(1),a5591. https:// } \\
\text { doi.org/10.4102/hts. } \\
\text { v76i1.5591 }\end{array}$} \\
\hline \multicolumn{2}{|c|}{$\begin{array}{l}\text { Copyright: } \\
\text { (c) 2020. The Authors. } \\
\text { Licensee: AOSIS. This wor } \\
\text { is licensed under the } \\
\text { Creative Commons } \\
\text { Attribution License. }\end{array}$} \\
\hline \multicolumn{2}{|c|}{ Read online: } \\
\hline 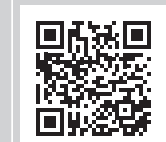 & $\begin{array}{l}\text { Scan this QR } \\
\text { code with your } \\
\text { smart phone or } \\
\text { mobile device } \\
\text { to read online. }\end{array}$ \\
\hline
\end{tabular}

Homelessness and its various forms of manifestation are a complex phenomenon. Street homelessness, which is the subject of this study, continues to be a challenge for the South African people and government. Different research studies have been undertaken on street homelessness. Various frameworks have been used in an attempt to understand and respond to street homelessness. Churches continue as key role-players in responses to street homelessness. There is a need, however, for churches to continually evaluate the various approaches to street homelessness, with a view to sharpening those approaches to better understand and respond to the challenge. Churches need frameworks that can help them to theologically understand and adequately respond to street homelessness. Gustafson's framework of moral engagement is explored within the context of street homelessness, with a view to suggest ways and means by which the Methodist Church of Southern Africa (MCSA) could better understand and adequately respond to the problem of street homelessness in South Africa.

Keywords: street homelessness; homelessness; moral discourse; poverty; churches.

\section{Introduction and background}

There is an increase in street homelessness in South Africa. Scholars (i.e. De Beer 2015; De Beer et al. 2015:3; Roets et al. 2016:624) observe that statistics on street homelessness portray an upward trajectory.

Street homelessness as a phenomenon is complex and defies simplified definitions (De Beer 2015:2; Roets et al. 2016:624; Sanchez 2010:102; Somerville 2013:384). Although it presents in various ways, street homelessness is a visible manifestation of being without shelter (Naidoo 2010:129).

People of all ages, young and old, have over time been known to live in the streets as homeless. In some instances, those who live in the streets are young mothers with young children (Aratani 2009:3-4). It is also observed that the street homeless communities in South Africa, for example, are made up of both citizens and non-citizens, who remain social outcasts in societies. Cross et al. (2010) observe that:

$[T]$ he street homeless are the proverbial skeletons at the feast, the excluded poorest who enter unobserved and stand by gaunt and starved, terrifying to the invited guests but deprived of any capacity to join the party. (p. 18)

Homelessness in general is an international problem linked partly to poverty (Moxley, Washington \& McElhaney 2012:436). In many instances, poverty and unemployment are the general causes of homelessness. However, homelessness remains a challenge for both the developed and developing countries. Cross et al. (2010:7) are of the view that poverty alone is not the problem.

Not all street homeless are poor. For some, especially in developed countries, as Cross et al. (2010) says:

... [T] he cause of their homelessness is often economic or social displacement and downward mobility rather than pre-existing poverty. (p. 16)

Personal challenges like family breakup or substance abuse contribute to people becoming homeless. In developing countries such as India, the state has limited control over influx of the poor in the streets (Cross et al. 2010:9). The government tries to clear the streets off people by providing housing, yet there is a constant growth of street homeless communities, as people move from rural areas to the cities. 
Cross et al. (2010:9) lament that homelessness has not ended even after improvements in welfare benefits.

\section{Street homelessness in South Africa}

In South Africa, location, causes and the makeup of the homeless community vary. In their work, Roets et al. (2016:617) confirmed that there are different types of homelessness in South Africa. According them, an average of $54 \%$ of the evidence used in their critical appraisal showed that the homeless population was made up of unemployed adult men and street dwellers. Cross and Seager (2010:145) examined the Human Sciences Research Council 2005-2008 study of street homelessness in South Africa and estimated that the number of homeless people in South Africa varied between 100000 and 200000. The estimated numbers are high because of the high rate of mobility within the homeless population. Lack of comprehensive data on the street homeless creates a challenge for policy-makers and legislators in their attempts to form policy frameworks that address street homelessness (Cross et al. 2010:6). Research is often conducted on the street homeless but conclusions are based on assumptions because of their constant mobility.

Although homelessness affects all races in South Africa, black people make up a large percentage of the street homeless (De Beer 2015:2; Roets et al. 2016:620). Those who live in the South African streets include South African citizens and migrants who have fled from various socio-political and economic challenges in their home countries. According to De Beer et al. (2015:3), the appearance of homelessness in South Africa has changed since the new democratic dispensation (see also De Beer 2015; Roets et al. 2016:624).

Previously, the street homeless have been mostly men, but lately women, children and the elderly live on the streets. Women and children are the most vulnerable of the street homeless. On various South African streets, children can be seen begging. There are reports of sexual abuse meted on children living in the streets (Roets et al. 2016:625). In fact, according to Tembe (2015:39), in order to survive, street homeless women engage in sex trade in exchange for food or other necessities.

Life in the South African streets is a constant daily challenge for the homeless. According to Naidoo (2010:131), the street homeless were found living in streets, in public toilets or under bridges, without a fixed place of abode. The street homeless struggle to store their belongings including food. Finding food and a place to sleep is a constant challenge for the street homeless (Thexton 2014:69). As a result, some street homeless people walk around with their little belongings from place to place, as they search for employment, food or a place to stay.

With no shelter and reliable accommodation, those who permanently live on the streets live from hand to mouth. Begging is the most common feature amongst the homeless. It is a daily survival strategy that the homeless employ in order to get food or money. Beggars are visible on street pavements and along traffic lights and their needs vary (Cross et al. 2010:17; Tembe 2015:39).

The homeless struggle for access to food. If they access food, it is often not of good nutritional quality (Tembe 2015:39). Sadly, but true, often, some street homeless people search for food from rubbish bins (Ezutah 2010:199). In addition, finding food may include making the rounds to the resource centres that provide food (Thexton 2014:69). This means walking to different places, such as churches, that give out food parcels or cooked meals. The frail and sickly street homeless people, tend to face challenges whilst reaching such places and are likely to go without food.

Securing employment is difficult for the street homeless, and they end up making a living from odd jobs, begging and sometimes even resorting to crime. Educated homeless people may have a chance of getting temporary employment, whilst the uneducated find it difficult (Roets et al. 2016:625). Although some of the street homeless people try to secure employment, they fail to do so because of various reasons, such as lack of education, identity documentation, qualifications, criminal records and physical challenges (Thexton 2014:84). Other means of making a living for the street homeless include recycling. Apart from collecting recyclable materials such as metals, bottles and cardboard papers, some homeless people try to make a living through washing cars, assisting taxi drivers by filling taxis with passengers or doing odd jobs in construction companies, helping carry luggage of shoppers in malls or shopping complexes (Makiwane, Tamasane \& Schneider 2010:40; Tembe 2015:39). However, securing these odd jobs come with difficulty.

Violence and crime, either as victims or as perpetrators, is another daily challenge for the street homeless. It becomes difficult for the street homeless to acquire any property because of the context in which they live, which is often characterised by crime and violence (Thexton 2014:121). The streets are not safe for all ages and genders, and even more so for women. Women are said to keep close relationships, both for security and economic purposes. Makiwane et al. (2010:46) and Thexton (2014:121) concur that in order to protect each other against rape and robbery, street homeless women keep close bonds as it is risky for them to sleep in open areas. Drugs are easily accessible for homeless people. The abuse of drugs becomes both a survival strategy and escapism from the reality of homelessness and the many challenges associated with the phenomenon (Tembe 2015:39). Makiwane et al. (2010:41) conclude that the most desperate coping mechanisms for survival on the street include robbery and drug trafficking.

Access to basic health is one of the rights enshrined in the South African Constitution. However, for the street homeless, this right continues to be elusive, as some of them do not have identity documents, which make it difficult to be assisted (Khoza 2014:26).

Lack of a place to stay or a place to call home makes the street homeless seem like criminals. Cross et al. (2010) state that: 
... [C]riminalisation of the street homeless emerges from concerns of the business community and other economically committed interested groups who perceive the need to avoid having poverty evident on the city streets. (p. 18)

Business people seem to be concerned with attracting investors to their towns and cities and therefore do not want the street homeless who usually make the street corners and building walls their homes.

There are reported cases of mistreatment of the homeless at the hands of law enforcement officials.

Reporting on Pathways out of street homelessness, Mashava (2015:36) states that migrants living on the streets of Pretoria allege that the police tend to ill-treat them. Mashava further notes that one of the cruel acts by the police is taking away the blankets of the homeless on cold winter nights. According to Du Toit (2010:7) and Khoza (2014:27), physical assault by the police is another form of abuse experienced by the street homeless.

\section{Causes of street homelessness}

A home is a place of nurturing relations. Broken relationships such as, but not limited to, dysfunctional families, divorce, domestic violence and abuse push people to become homeless (Makiwane et al. 2010:40; Nixon 2016:67). It is posited that many children raised singlehandedly by divorced parents, single parents, street homeless parents or relatives, whilst parents go to big cities, tend to live on the streets (Makiwane et al. 2010:42). Unstable and poor household upbringing and disintegration of families contribute to growing numbers of street homeless people of all ages and single-parent families (Philipps 2012:5; The Methodist Church of Southern Africa [MCSA] 2007:14). Constant family moves are another trigger of homelessness from an early age. Philipps (2012:7) argues that the stress associated with settling in and creating new relationships creates isolation and insecurity, which results in other children, even adults, failing to adapt to new communities and ending up living in the streets.

Some street homeless people have a history of substance abuse (Daya \& Wilkins 2013:10; National Coalition for the Homeless 2009). For some people, substance abuse has been a strategy of coping with life challenges such as broken relationships (Nixon 2013:93). Such usage became a habit and eventually a lifestyle that led them to street homelessness. Therefore, substance abuse makes it difficult for people to leave the streets and be re-integrated into living in a home. Although substance abuse is a coping strategy for others before being homeless (Nixon 2013:93), the continued abuse of substances is for coping with harsh street life experiences (National Coalition for the Homeless 2009; Makiwane et al. 2010:41). The street homeless use and abuse substances in order to escape the hard realities and lived experiences in streets.

Occasionally, people living with sickness and disease become homeless (Nixon 2013:78). Lacking holistic care and support, when health challenges befall them, some people turn to the street. Health and wellness are essential for a healthy society. Mental illnesses tend to push some to live in the streets. According to the National Coalition for the Homeless (2009), substance abuse and mental illness are a reality in the lives of many homeless people.

Those who get injured at work or contract diseases from their work environment are forced to leave employment. They also fall into homelessness as they cannot afford rental accommodation (Nixon 2013:94).

Domestic violence is a contributing factor to street homelessness (Aratani 2009:5). Some people move away from their homes to the streets for personal safety. Not many towns and cities have shelters, and in the absence of these centres, the streets become safe havens. Baker, Cook and Norris (2003:754-755) observed that it is mostly women who become victims of domestic violence and are forced to leave their homes and become homeless. The effects of violence on children and youths are equally devastating. Some of these children and youth run away from home after experiencing violence (Aratani 2009:5; Philipps 2012:8).

South African history informs and influences street homelessness. During the apartheid era, laws that were enacted ensured forced removal of non-whites from their previously owned lands and houses (Cross et al. 2017:17). Apartheid, a political and economic system of separation based on laws and acts, such as the Group Areas Act, had hostile effects on people's livelihoods. As such, Olufemi (1998) states:

The problem of squatting and homelessness in South Africa dates back to the apartheid period and, until recently, squatting on the Witwatersrand always took the form of shacks in the backyards of formal township stands. (pp. 224-225)

It is reported that a number of South Africans have migrated from rural areas into cities. Such migrations may be necessitated by the need of employment opportunities in the city. When migrants are not able to secure employment, they become displaced, dislocated and therefore end up living in the city streets (Botha 2013:106; Louw 2016:3; Schenck et al. 2017:271).

The dawn of democracy brought with it hope for transformation. Unfortunately, some people still find themselves in the streets. Unfair and unequal distribution of resources, corruption and poor implementation of government policies render many people homeless. South Africa is still facing with the effects of apartheid. The hostility with which non-white South Africans suffered during apartheid has recently been directed to non-South African migrants (MCSA 2009:18). During xenophobic attacks, many non-Southern African citizens, some of whom had property, including accommodation, found themselves in the streets. The Central Methodist Mission was one of the places that became a safe haven for the evicted (Kuljian 2013:76).

Even though the South African Housing Policy (SAHP) attempts to respond to homelessness in South Africa, the 
challenge of homelessness persists (Cross et al. 2010:6-7). The housing policy as formulated by the South African National Department of Human Settlements focusses mainly on those living in informal settlements and those with meagre salaries who cannot afford good living conditions (National Department of Human Settlements 2010:4-29). Naidoo (2010:132) argues that street homelessness is not only about lack of shelter, but also has close connection with social and economic conditions. In addition to being unemployed and lacking shelter, the street homeless also lack access to other basic rights as enshrined in the South African Constitution. For example, the Bill of Rights lists the basic rights as the right to housing, healthcare, food, water and social security (Juta Statutes Editors 2015:14). These rights are envisioned to be enjoyed by all citizens. As such, it is the duty and responsibility of the South African government to ensure that all citizens, including those who live in the streets, enjoy these benefits.

The housing policy in South Africa is the declaration by the government on how low-cost houses are to be provided for the citizens (Meyer 1997:150). Sadly, in the housing policy there is a barrier, in that it stipulates who qualifies to get a housing subsidy. That qualification assessment is based mainly on minimum income that the unemployed and street homeless do not have. Although the National Housing Policy (National Department of Human Settlements 2010:4-29) lists different programmes aimed at providing housing assistance to various people, the homeless do not have access to these programmes. The criteria to access these programmes mostly require an indication of form of financial security plus identity documents which the homeless people may not be in possession of.

Churches, just like governments, have attempted variously to attend to the challenges of street homelessness. Christian communities are driven by the golden rule, 'Do unto others

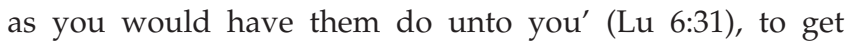
involved in street homelessness. Outreach programmes offered by churches help the homeless in areas where the government is unable to assist (Roets et al. 2016:622). In Johannesburg and Pretoria alone, there are 12 Christian organisations that serve the homeless in the streets (Sanchez 2010:103). On the flipside, there were reports that indicate that some churches operate in ways that appear to worsen the conditions of those who live in the streets. De Beers (2015:8) notes that instead of embracing the homeless, some churches chase them away by opening sprinklers on them. Instead of becoming places of refuge, such churches expel those in need. Mashau and Mangoedi (2015:2) lament the fact that some religious communities, contrary to their nature of being receptive, have become places of social exclusion against the marginalised.

\section{Moral discourse as a theoretical framework to better understand and respond to street homelessness}

We propose that the varieties of moral discourse advanced by Gustafson (1988) are a useful framework that could assist churches to better understand and respond to the challenge of street homelessness.

Gustafson's (1988:4-5) varieties of moral discourse, namely, prophetic, narrative, ethical and policy, are here proposed as a lens upon which the mission of churches amongst the street homeless could be critiqued. Gustafson's varieties of moral discourse evaluate what churches do when they engage in moral-ethical issues. These various discourses are helpful in showing that moral engagements can be done in different levels, without one approach or mode being valued more than the other (De Villiers 2012:4).

\section{Prophetic discourse}

Prophetic discourse is neither a form of predictive seer discourse nor a scholarly Biblical discourse; however, its foundation is on the prophetic pronouncements found in the Bible (Gustafson 1988:7). There are two aspects of the prophetic discourse that Gustafson $(1988: 7-8,13)$ focusses on: moral or religious indictments and utopian. The basis of prophetic discourse is on the Biblical prophets, their warnings and visions of a better future. Gustafson (1988) refers to this aspect as an indictment against the real situation. As such, through prophetic discourse churches challenge institutions, structures and systems to work towards the utopia.

The prophetic discourse critiques, through confrontational language, evil that is seen and/or experienced in society. According to Gustafson (1988):

It is the word of the Lord proclaimed against the moral evil and apostasy of the world and societies. (p. 8)

The major features of indictments are the critique of the root causes of the evil witnessed, together with the language and symbols used to demonstrate it.

Churches are called upon to critique and confront powers that alienate the street homeless from participating in the democratic South Africa. These structures and systems must be confronted with the aim of bringing about change. Inhumane living conditions that the street homeless live in indicate a misplaced ethical value and respect for people (De Beer 2015:4). Through prophetic discourse churches must proclaim the dignity of the street homeless, who are created in the image of God. Access to adequate housing goes a long way in affirming their dignity (Renkin 2015:12).

Through indictments, churches address the root causes of moral degeneration. In the case of street homelessness, churches are engaged with moral issues, such as poverty, unemployment and corruption, so that street homelessness is adequately responded to. According to De Villiers (2012), the indictments:

... [D]o not analyse possible solutions to quite specific problems, but rather get to the roots of systemic evils that pervade institutions and cultures or the actions and behaviour of individual persons. (p. 4) 
The purpose of the indictment is for transformation from a state of helplessness and hopelessness into that of life in its fullness. According to Gustafson (1998):

Prophetic discourse generally looks for a demon, a power, or source, which presumably underlies all the numerous signs of what is wrong in society. (p. 11).

The conviction is that once the pronouncement has been made, the targeted structures will be moved to effect change.

Another feature of the moral indictment is the use of language and symbols in confronting the moral evil experienced. The language used in a prophetic discourse cuts to the heart. According to Gustafson (1998), '... Its practical end is to evoke deep moral response; it moves us' (p. 13).

The Methodist Church of Southern Africa (MCSA), for example, is aware of the existence of the street homeless and has made pronouncements in its conferences to that effect. The MCSA (2007) states that ' $t$ too many young people remain illiterate and face homelessness and joblessness' (p. 33).

In an attempt to understand the plight of the poor and the destitute, the MCSA has sought for theologies that affirm life whilst speaking to the government (MCSA 2008:15). Whilst addressing a conference in 2007, the Presiding Bishop of the MCSA made it clear that those elected into public office need to be held accountable, stating that as a church, the MCSA needs to speak truth to power, even at the expense of being unpopular (MCSA 2008:15). The MCSA felt that the plight of the marginalised that is manifested in various forms is not treated with the same urgency as other government programmes in South Africa. For example, before the 2010 Soccer World Cup, the government, private and public sectors worked tirelessly to ensure the success of the tournament.

However, when it came to issues of concern regarding the marginalised, the urgency was not there. It would be beneficial to the marginalised if such zeal and enthusiasm were used in working towards the eradication of poverty, homelessness and other social ills (MCSA 2012:63). The MCSA confesses to be a church in solidarity with the poor (Vika 2008:66).

The MCSA's mission work amongst the poor is done through, although not limited to, feeding schemes, soup kitchens, selfhelp projects, farming activities, vegetable gardens, sewing and knitting skills and day care ministries. The 2007 Mission Unit (MU) report of MCSA (2008) captures this work well:

The MU acknowledges with excitement the sterling services rendered at district, circuit and society levels of our church in addressing the plight of the poor, sick, homeless, destitute, refugees, unemployed, orphaned and abandoned people throughout the Connexion. The MCSA community hosts projects such as: soup kitchens, orphanages, prisoner care, home-based care providers, hospital care groups, skills development and job creation initiatives, among others. (p. 143)

The work of the MCSA, although commendable, has not brought about the total eradication of street homelessness.
We acknowledge that the MCSA's mission has tended to focus on the main agenda, on immediate relief and welfare (Korten 1990:115). Often these responses sustain dependency and complete transformation is not realised.

Gustafson (1988:16) is of the view that prophetic discourse on its own is not enough. He adds that it requires verification of facts which enable a clear understanding of complex issues associated with the confronted root cause.

The ministry of the MCSA is indicative of a prophetic discourse to both internal and external migrants during the various incidences of xenophobic attacks in South Africa. Displaced and destitute migrants were given shelter and provided with food and clothing. This gesture confronted the South African Christian community of the hospitality code that Jesus had challenged his audience with in Matthew

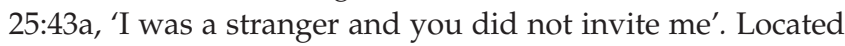
on Pritchard Street in downtown Johannesburg is the Central Methodist Mission (CMM), whose involvement with street homelessness made newspaper headlines in May 2008 (Kuljian 2013:1-7). The CMM provided accommodation in the sanctuary to thousands of children, women and men, mostly non-South African migrants. Educational, recreational, nutritional and entrepreneurial programmes were offered to the street homeless (MCSA 2008:52).

\section{Narrative discourse}

Storytelling is probably one of the most valuable tools used in transferring traditions and information from generation to generation. In some cases, the narration is done through dramatisation, whilst in some other cases it is done through artistic and creative use of language. Gustafson (1988:19-20) states that narratives function firstly as shaping ethos of a religious community and secondly as sustaining the moral identity of a community through the rehearsal of history and traditional meanings as portrayed in scripture or other sources. Each community has a narrative that either influences or is influenced by. Richardson (2009:48) states that stories are not only meant to entertain or captivate, but they are also the creators and markers of a community. Oral tradition and the transfer of moral values from one generation to another are accomplished through storytelling.

The narrative discourse is concerned with the people and what makes them a community. Koopman (2004) points out that:

The focus is on people, their identity, the communities that they belong to, the narratives that form them, and the significant others, role models and moral heroes that inspire them. (p. 445)

Narratives function to sustain the particular moral identity of a religious or secular community by rehearsing its history and traditional meanings, as these are portrayed in scripture and other sources (Gustafson 1988:19). The parable of the sheep and the goats can be a useful narrative in persuading communities to be considerate of the less fortunate by creating spaces that encourage their positive livelihoods. In that way they can avoid landing on the streets. 
Gustafson (1988:20) speaks about the prophetic and choicemaking function of the narrative discourse. In the prophetic function, people share their lived experiences about the conditions they live under. The effect of the stories convicts the systems that are responsible to change their condition or that are in a position to intervene but choose not to do so. Through narratives, those responsible for making decisions are challenged to make choices as a response to the confrontation.

There is no indication in the MCSA's MU reports and the Minutes of Conference that the MCSA employs narratives in its responses to the challenge of street homelessness.

\section{Ethical discourse}

In ethical discourse, Gustafson (1988:33) refers to philosophical modes of argument and analysis of society's moral norms. It is worth considering whether the principles and values discussed from a faith community perspective are applicable to all people or only to those who subscribe to that faith. In other words, are these values shared by all people living in a particular context or exclusive to those of a particular faith? The issue of street homelessness affects people from all walks of life, and as such the values of one faith cannot be held against or above others when trying to assist the street homeless.

Through ethical discourse churches evaluate themselves on those principles that they teach, such as hospitality, love and care. In the midst of increasing numbers of street homeless people, the church should ask if there are justifiable reasons why people become street homeless, and under what conditions are those reasons justifiable? Are there morally and unjustifiable reasons of street homelessness? Gustafson (1988:41-42) claims that an extensive use of ethical discourse in religious communities is a beneficial achievement.

When churches challenge unfair distribution of houses, they need to have good and informed use of what they mean by just distribution. According to Gustafson (1988):

Ethical discourse provides the concepts, the modes of appropriate argumentation, and important distinctions which lead to greater precision and stronger backing for what Christians and other religious communities think is the good thing to do. (p. 42)

This is stated differently by Koopman (2012) as '[e]thical discourse, ... encourages a more precise use of concepts like justice, virtue, rights and duties' (p. 5).

How can the MCSA engage the challenges of street homelessness from an ethical discourse standpoint?

\section{Policy discourse}

Policy discourse is about considering documents and policies that seek to recommend or prescribe a particular course of action (Gustafson 1988:45). This means looking at various sources of information and weighing all the advantages and disadvantages associated with a proposed decision or action. Various assessments and considerations are carried out before a solution is reached. Policy discourse has two features. Firstly, it is done by people responsible for making choices and decisions and acting upon those choice or decisions (Gustafson 1988:46). Secondly, it is concerned with the conditions under which a policy is developed (Gustafson 1988:46).

\section{According to Gustafson (1988):}

Churches and Christians who aspire to affect the course of events with moral aims and principles need to be able to participate in policy discourse. (p. 520)

Churches need to be involved in decision-making and policymaking forums. Churches take part in ethical discourse to ensure that those responsible for making policies are not biased. As Gustafson (1988) claims:

The persons responsible for policy have to be sensitive to their own positions of power: what is required to gain and retain the offices they hold that authorize them to determine policy? (p. 46)

The MCSA has taken part in various policy discourses. The church's theology teaches that (The Methodist Church of Southern Africa 2006):

God calls us to champion the needs of the people especially the poorest, in our relationship with Government: We must challenge promises that are not kept and protest excessive expenditure through public statements. (p. 27)

It was reported in the 2015 MCSA Conference that there had been positive outcome in the engagement with various institutions regarding evictions (MCSA 2016:180). The report further stated that in one locality where people faced eviction, those people were given new plots and assisted with building material to build their homes. The MCSA understands its moral, ethical and theological responsibility of standing alongside the marginalised and poverty-stricken people. As such, the MCSA (2009) states that:

We need to stand alongside people in the discourse and policy process of their struggles for dignity as they know best what affects them and how best their conditions can be overcome. (pp. 14-15)

Gustafson's (1988) four varieties of moral discourses are a useful framework that can assist churches in the evaluation of the ministry of the MCSA towards those that live on the streets.

\section{Implications of Gustafson's varieties of moral discourse for the Methodist Church of Southern Africa's mission on street homelessness Intentional confrontation}

The MCSA must be intentional in its critique of street homelessness and the causes thereof. Confrontation of the present status of street homelessness should be directed towards the various levels of government.

Structures and systems responsible for the provision of basic housing should be confronted. The government should be critiqued for its policies on poverty eradication and 
their effectiveness through such avenues as press releases, demonstrations and sermons.

Even though the MCSA is engaged in prophetic discourse, it seems its prophetic voice is mainly directed at the MCSA members. The prophetic voice is not loud enough for the government to hear. Vika (2008:66) argues that at the advent of democracy, the church lost its prophetic role. Instead of confronting politicians and public officers when they did not represent the interest of the citizens, the state and public officers, the church drifted away from calling these structures into accountability.

After 1994, the MCSA is amongst churches that occupied places of social prominence in the democratic South Africa (Forster 2016:63). Forster (2016:68-69) further notes that Rev Mehana, a senior MCSA minister who is the Chaplain General to the Africa National Congress (ANC) had before 2014 national elections encouraged ministers to vote for the ANC. Forster adds that there have been debates from South African churches and discussions from within the MCSA to have ministers withdraw political party chaplaincy. After deliberations, the MCSA Conference (2015) took a decision, namely, that:

Conference resolves not to deploy ministers as Chaplains to political parties and further calls on Ministers in such situations to withdraw from such appointments. (p. 90)

The MCSA holds the view that the Lordship of Christ extends to all people including politicians, and therefore, does not withhold ministry to politicians and government leaders (Forster 2016:72; MCSA 2016:235). The MCSA neither supports nor favours any political grouping.

In view of this, the MCSA and all its members, both clergy and laity in their individual work, and in institutions of power, should be prophetic. District bishops (official head and principal pastors of districts) and the Presiding Bishop (official head and chief pastor of MCSA) generally have the authority to engage the media on issues of concern (MCSA 2016:56; 67). However, that does not prevent other members in their various capacities to be prophetic in line with the teachings and doctrines of the MCSA. Liturgies and sermons, for example, should challenge unjust distribution of resources that contribute to street homelessness. The prophetic mode draws from Biblical prophecy; therefore, liturgies challenging street homelessness can be made with reference to both Old and Testament scriptures.

Developing a confessional prayer from Isaiah 65:21a and 22a, which reads ' $t]$ hey will build houses and dwell in them; no longer will they build houses and others live in them', can be an example. Invoking this passage as a confession on the part of the church can move members to find ways of responding to street homelessness. One of the elements of prophetic discourse is to move people to action.

\section{Tell a story: Build a community}

Storytelling can be an effective tool of community building for the MCSA in its mission work concerning the street homeless. Narratives are educational, and the church can be a vehicle through which communities would be formed morally. The MCSA, with and for the street homeless, can and should create spaces and time for the street homeless to tell their story. In that way, when the MCSA engages in its mission work for the street homeless, it will be from an informed position. The MCSA should revive its Methodist traditions through storytelling. Care for the poor in the 18thcentury England, for example, where Methodism traces its roots, is filled with narratives that fill Methodists with pride. Such narratives include one where Wesley, the founder of Methodism, urged communities to support the poor through self-help measures and charitable deeds to relieve distress (Marquardt 1992:28).

Methodism and social aid to the poor grew out of Class Meetings (Marquardt 1992:28). Class meetings were small groups of Methodist members who held each other accountable in spiritual formation and cared for each other pastorally (Hulley 2006:27-28; Storey 2004:21). It was through Class Meetings that social ills like poverty that affected society members were discussed and solutions were identified. Through telling such stories, the MCSA members can be challenged to explore means of assisting the street homeless. Wesley argued that there is no holiness but social holiness, stressing the importance of loving one another in word and deed. Wesley did not only advocate for the poor but journeyed with them in their predicaments. That is why his teaching on the preferential option for the poor carried much weight. As Storey (2004) states:

When he was with the poor he found that he had unknowingly arrived at Jesus' home address - that Matthew 25 is true: Jesus is found among the sick, naked, hungry and captive. (p. 40)

Therefore, through sharing these Methodist stories, the MCSA can revive the Methodist original goal of mission, namely, to spread scriptural holiness in the land.

Just as Wesley often shared meals with the poor (Marquardt 1992:34), MCSA members can forfeit the pleasure of worshipping in nicely furnished church halls and go to where the street homeless are and worship with them. Other means could be to join the street homeless in their daily life experience so that the MCSA members can be better advocates for the street homeless. Worship liturgies featuring street homelessness and an avenue for testimonies by the street homeless during worship services can assist the housed communities to better appreciate the challenges faced by those who live in the streets and be compassionate to the street homeless. Together, the worshipping community and the street homeless can then journey towards healing and transformation.

It is notable from the MU reports that the MCSA provides various kinds of assistance to the street homeless. But there is no indication of active engagement on what it means for the street homeless to be street homeless. The MCSA continues to assume the role of a donor that views the street homeless as helpless clients who depend on its donations. However, as 
the Asset-based Community Development (ABCD) approach to development suggests, developers need to view the street homeless as citizens who have abilities to bring transformation in their situation. All they need is a little help that includes relocation of power from the powerful to the weak. Mathie and Cunningham (2005) state that:

The process of recognising these capacities begins with the construction of a new lens through which communities can begin to assemble their strengths into new combinations, new structures of opportunity, new sources of income and control, and new possibilities for production. (p. 476)

The aforementioned can be achieved through storytelling in various forms.

The Tshwane Homeless Summit held in 2015 as a joint venture between the homeless, local government and the University of Pretoria is an example of how, in narrative discourse, various stakeholders can engage street homelessness (De Beer et al. 2015:53). Creative writing and drawing are demonstrated in the summit report as a way that defined street homelessness and the various challenges faced by the street homeless. The MCSA can learn from this event and create similar exercises. Artistic use of confrontational language is a tool through which the MCSA can better understand and better engage street homelessness.

Additionally, the vision of a better place and good livelihoods, as presented in Isaiah 65:17-25, can be a good narrative to engage both the MCSA members and various stakeholders on street homelessness. As Isaiah (65) states:

They will build houses and dwell in them; they will plant vineyards and eat of their fruit. No longer will they build houses and others live in them, or plant and others eat. The wolf and the lamb will feed together, and the lion will eat straw like the ox, ... (vv. 21-22; 25a)

This text addresses the issue of unfair distribution of resources which has negative effects on the poor. Some of the rich and powerful, and public officers, who are made responsible for bringing social transformation, tend to keep the poor and powerless on the margins. Using this text in sermons, workshops, conferences and other gatherings, the MCSA members are challenged into actions that may lead to better engaging street homelessness.

Another tool that can be useful is the Contextual Bible Study (CBS) that follows a 'see, judge, act' framework. The CBS is always situated within the social analysis and needs of particular communities of the poor, the working-class and marginalised (Ujamaa 2014:4). Through CBS the street homeless can share their embodied theologies. Furthermore, attempts at forming working relations with all community stakeholders can be fostered through forums, such as seminars and open-air meetings facilitated by the MCSA. It is in such platforms that those who are and those who were previously street homeless can share their pathways into and out of street homelessness.

\section{The Methodist Church of Southern Africa and ethics: An assessment of the good life}

The MCSA confesses to be a church that believes in spreading scriptural holiness, known variously as Sanctification and Christian Perfection (Storey 2004:35). There is a need for selfassessment within the MCSA on how well it has done in its efforts to help those who live in the streets, including how faithful the church is, towards its doctrines on social justice.

The teaching on preferential option for the poor, which calls on Christians to be in solidarity with the poor and the marginalised, is based on scriptural holiness. Wesley's teaching on preferential option for the poor encourages mission work in such a manner that issues of justice are dealt with (Storey 2004:40). This is what the MCSA can ethically and deliberately consider in its gatherings. Members should be asking themselves the following questions: how true are we to our Christian values and theological pronouncements? Is our dealing with the street homeless consistent with our determined solidarity with the poor? (MCSA 2014:229). This requires an undertaking and consideration of the street homeless as citizens made in the image of God. In that way, mission work done in and for the streethomeless will not be treated flippantly, but as participating in God's liberating mission.

Before external stakeholders are engaged on street homelessness, the MCSA should start within itself and see what resources it has, which could be useful in engaging street homelessness. We opine that mission work can be executed through various mission groups, such as the Women's Manyano, the Women's Auxiliary and the Young Men's Guild, to mention but a few. It is through these organisations that spirituality, fellowship and social holiness are nurtured (Ketshabile 2006:104).

\section{Advocacy and partnership in policy-making}

We suggest two strategies that the MCSA can employ in engaging policy-makers on housing issues:

Firstly, through its members in positions of power and influence in policy-making, the MCSA can ensure that actions and outcomes are followed. It is essential for the MCSA's mission coordinators in all districts to engage such members in their mission work amongst the street homeless.

Secondly, the MCSA should facilitate policy engagements between the street homeless and government structures so that eventually the streets can be cleared of people. Without engaging the street homeless, speaking and acting on their behalf, the MCSA cannot be able to fully grasp what the desired condition of the street homeless is. This argument is based on the fact that there are various reasons as to why people are homeless.

Some are street homeless because their homes are not a place of safety; others are street homeless because although they are employed, they cannot afford rented accommodation; yet others are street homeless because of general poverty and 
unemployment. Therefore, the MCSA should engage policies that affect people's coping strategies and suggest to policymakers ways that can avert people falling into street homelessness.

In ideal situations, policy and decision-makers need to be engaged before people find themselves in homelessness. In other words, ethical and policy discourses must be proactive so that issues like street homelessness are avoided before they happen. The MCSA's mission coordinators have to be on the alert for any proposed policy and legislation that is likely to have a negative impact on people's lives, and engage structures and the government before people experience hardships.

The church should not only be a voice of the voiceless (Registre 2017:1); instead, the church should create a space that allows the street homeless to engage policy-makers and decision-makers directly. Blasi (2001) states that:

Advocacy requires, among many other things, changing how more powerful people understand the circumstances of the less powerful. (p. 1)

It is important that the MCSA understands the conditions of the street homeless from their (the street homeless) perspective. This means a paradigm shift in terms of the perceptions that the housed community understands and engages with the street homelessness.

\section{Conclusion}

Street homelessness is a complex phenomenon caused by many factors, including poverty. The street homeless live in inhumane conditions. Their survival strategies question the applicability of the basic human rights in their context. Gustafson's four modes of moral discourse can be very helpful to the MCSA's understanding of and responses to street homelessness.

\section{Acknowledgements}

\section{Competing interests}

The authors have declared that no competing interests exist.

\section{Author's contributions}

All authors contributed equally to this work.

\section{Ethical consideration}

This article followed all ethical standards for a research without direct contact with human or animal subjects.

\section{Funding information}

This research received no specific grant from any agency in the public, commercial or not-for-profit sectors.

\section{Data availability statement}

Data sharing is not applicable to this article as no new data were created or analysed in this study.

\section{Disclaimer}

The views and opinions expressed in this article are those of the authors and do not necessarily reflect the official policy or position of any affiliated agency of the authors.

\section{References}

Aratani, Y., 2009, Brief homeless children and youth: Causes and consequences, National Center for Children in Poverty, Columbia University.

Baker, C.K., Cook, S.L. \& Norris, F.H., 2003, 'A aontextual analysis of women's helpseeking, received informal support, and formal system response', Violence against Women 9(7), 754-783. https://doi.org/10.1177/1077801203009007002

Blasi, G., 2001, 'Advocacy and attribution: Shaping and responding to perceptions of the causes of homelessness', in S.D. Watson (ed.), Representing the poor and the homeless, pp. 1-20, American Bar Association, Washington, DC.

Botha, N.A., 2013, 'A theological perspective on migrants and migration focussing on the Southern African Development Community (SADC)', Missionalia 41(2), 104-119. https://doi.org/10.7832/41-2-8

Cross, C., Seager, J., Erasmus, J., Ward, C. \& O'Donovan, M., 2010, 'Skeletons at the feast: A review of street homelessness in South Africa and other world regions', Development Southern Africa 27(1), 5-20. https://doi.org/10.1080/03768350 903519291

Cross, C. \& Seager, J.R., 2010, 'Towards identifying the causes of South Africa's street homelessness: Some policy recommendations', Development Southern Africa 27(1), 143-158. https://doi.org/10.1177/1474474012469886

Daya, S. \& Wilkins, N., 2013, 'The body, the shelter, and the shebeen: An effective geography of homelessness in South Africa', Cultural Geographies 20(3), 1-36. https://doi.org/10.1177/14744774012469886

De Beer, S.F., 2015, 'Ubuntu is homeless: An urban theological reflection', Verbum et Ecclesia 36(2), 1-12. https://doi.org/10.4102/ve.v36i2.1471

De Beer, S., Mashau, T., Kriel, I., Kriel, J., Renkin, W. \& Hamati, R., 2015, 'Pathways out of homelessness: Recommended policy and strategy on street homelessness in the City of Tshwane', viewed 3 May 2019, from https://tshwanehomelessresearch. the City of Tshwane, viewed 3 May 2019, from https://tshwanehomelessresearch. homelessness-in-the-city-of-tshwane.

De Villiers, D.E., 2012, 'Do the prophetic and reformist approaches in Christian Ethics exclude one another? A responsibility ethics attempt at reconciliation', In die Skriflig 46(1), 1-8. https://doi.org/10.4102/ids.v46i1.38

Du Toit, 2010, 'Local metropolitan government responses to homelessness in South Africa', Development Southern Africa 27(1), 1-20. https://doi. org/10.1080/03768350903519390

Ezutah, G., 2010, Trail of immortality: Looking through the veil of eternity, Strategic Book Publishing, Durham.

Forster, D., 2016, 'A state church? A consideration of the Methodist Church of Southern Africa in the light of Dietrich Bonhoeffer's "Theological position paper on state and church"', Stellenbosch Theological Journal 2(1), 61-68. https://doi org/10.17570/stj.2016.v2n1.a04

Gustafson, J.M., 1988, Varieties of Moral Discourse, Calvin College and Seminary, Grand Rapids, MI.

Hulley, L.D., 2006, Wesley: A plain man for plain people, Methodist Publishing House, Cape Town.

Juta Statutes Editors, 2015, The Constitution of the Republic of South Africa, 14th edn., Juta, Cape Town.

Ketshabile, K.F., 2006, 'Wesley's Mission Model', in P. Malinga \& N. Richardson (eds.), Rediscovering Wesley for Africa, 2nd edn., pp. 97-104, The Methodist Church of Southern Africa, Education for Ministry, Pretoria.

Khoza, R.A., 2014, ‘Understanding homelessness through women's experiences and journey through it', Honours thesis, Faculty of Engeneering \& Built Environment, University of Witwatersrand.

Koopman, N.N., 2004, 'Let the plight of the voiceless be heard. Prophetic speaking about poverty today', NGTT/Nederduitse Gereformeerde Teologiese Tydskrif 45(1), 440-451.

Koopman, N.N., 2012, 'Public theology in pluralistic societies? Lessons from the theology of Etienne de Villiers', Verbum et Ecclesia 33(2), 1-6. https://doi. org/10.4102/ve.v33i2.773

Korten, D.C., 1990, Getting to the 21st century: Voluntary action and the global agenda, Kumarian Press, West Hartford, CT.

Kuljian, C., 2013, Sanctuary, Jacana, Johannesburg.

Louw, D., 2016, 'The refugee dilemma and migrant crisis: "Charity begins at home" or "being home to the homeless"? The paradoxical stance in pastoral caregiving and the inflitration and perichoresis of compassion', HTS Teologiese Studies/ Theological Studies 72(2), 1-11. https://doi.org/10.4102/hts.v72i2.3267

Makiwane, M., Tamasane, T. \& Schneider, M., 2010, 'Homeless individuals, families and communities: The societal origins of homelessness', Development Southern Africa 27(1), 39-49. https://doi.org/10.1080/03768350903519325

Marquardt, M., 1992, John Wesley's social ethic, Abingdon Press, Nashville, TN.

Mashau, T.D. \& Mangoedi, L., 2015, 'Faith communities, social exclusion, homelessness and disability: Transforming the margins in the Cit yof Tshwane', HTS Teologiese Studies/Theological Studies 71(3), 1-9. 
Mashava, V.R., 2015, Unsung populations: A study on the right to the city and how it influences the everyday lives of the homeless people in the inner city of Pretoria, s.n, Pretoria.

Mathie, A. \& Cunningham, G., 2005, 'Who is driving development? Reflections on the transformative potential of asset-based community development', Canadian Journal of Development Studies 26(1), 175-186. https://doi.org/10.4102/hts.v71i3.3088

Meyer, I.H., 1997, 'Low-cost housing under the Mandela administration', in S. Liebenberg \& P. Steward (eds.), Participatory development management and the RDP, Juta, Cape Town.

Moxley, D.P., Washington, D.G. \& McElhaney, J., 2012, '“I don't have a home”: Helping homeless people through faith, spirituality and compassionate service', J RElig Health 51(2), 431-449. https://doi.org/10.1007/s10943-010-9363-6

Naidoo, V., 2010, 'Government responses to street homelessness in South Africa', Development Southern Africa 27(1), 129-149. https://doi.org/10.1080/037683 50903519408

National Coalition for the Homeless, 2009, Substance abuse and homelessness, viewed 27 May 2019, from https://www.nationalhomeless.org/factsheets/addiction.html.

National Department of Human Settlements, 2010, National housing policy and subsidy programmes, viewed 15 May 2019, from https://www.kzndhs.gov.za/ Uploads/documents/Resource Centre/Legislation/National_Policies/National\% 20 Housing\%20Policy $\% 20$ and $\% 20$ Subsidy $\% 20$ Programmes.p pdf.

Nixon, D., 2016, Stories from the street: A theology of homelessness, Routledge, London. https://doi.org/10.4324/9781315610832

Olufemi, O., 1998, 'Street homelessness in Johannesburg inner-city: A preliminary survey', Environment and Urbanization 10(2), 223-234. https://doi.org/10.1177/ 095624789801000210

Philipps, K., 2012, Homelessness: Causes, culture and community development as a solution, viewed 07 May 2019, from https://digitalcommons.salve.edu/cgi/ viewcontent.cgi?article=1088\&context=pell_theses.

Registre, J., 2017, Inclusivus, viewed 12 May 2019, from https://inclusivus.org/ inpowered-perspectives/2017/3/8/why-we-should-avoid-becoming-the-voiceof-the-voiceless.

Renkin, W., 2015, 'Finding a prophetic response to end homelessness in the City of Tshwane: A transdisciplinary approach', Master of Divinity, Faculty of Theology, Department of Practical Theology, University of Pretoria.

Richardson, N., 2009, 'Morality and communality in Africa', in L. Kretzschmar, W. Bentley \& A. van Niekerk (eds.), What is a good life? An introduction to Christian ethics in 21st century Africa, pp. 43-56, AcadSA, Kempton Park.
Roets, L., Botha, A., Greeff, M., Human, S.P., Strydom, H., Watson, M.J. et al., 2016, 'A synthesis of homelessness in South Africa: A rapid critical appraisal', Development A synthesis of homelessness in South Africa: A rapid critical appraisal, Development
Southern Africa 33(5), 613-627. https://doi.org/10.1080/0376835X.2016.1203756

Sanchez, D., 2010, 'Civil society responses to homelessness', Development Southern Africa 27(1), 101-110. https://doi.org/10.1080/03768350903519382

Schenck, R., Roman, N., Erasmus, C., Blaauw, D. \& Ryan, J., 2017, 'Homeless in observatory, Cape Town through the lens of Max-Neef's fundamental human need taxonomy', Social Work 53(2), 266-287. https://doi.org/10.15270/53-2-568

Somerville, P., 2013, 'Understanding homelessness', Housing, Theory and Society 30(4), 384-415. https://doi.org/10.1080/14036096.2012.756096

Storey, P., 2004, And are we yet Alive? Revisioning our Wesleyan Heritage in a new South Africa, Methodist Publishing House, Cape Town.

Tembe, M., 2015, Challenges and survival strategies amongst the homeless in Pretoria Central, Unpublished, Pretoria.

The Methodist Church of Southern Africa (MCSA), 2006, Yearbook, Methodist Publishing House, Cape Town.

The Methodist Church of Southern Africa (MCSA), 2007, Yearbook, Methodist Publishing House, Cape Town.

The Methodist Church of Southern Africa (MCSA), 2008, Yearbook, Methodist Publishing House, Cape Town.

The Methodist Church of Southern Africa (MCSA), 2009, Yearbook, Methodist Publishing House, Cape Town.

The Methodist Church of Southern Africa (MCSA), 2012, Yearbook, Methodist Publishing House, Cape Town.

The Methodist Church of Southern Africa (MCSA), 2014, Yearbook, Methodist Publishing House, Cape Town.

The Methodist Church of Southern Africa (MCSA), 2015, Yearbook, Methodist Publishing House Cape Town.

The Methodist Church of Southern Africa (MCSA), 2016, The methodist book of order, 12th edn., Methodist Publishing House, Cape Town.

The Methodist Church of Southern Africa (MCSA), 2016, Yearbook, Methodist Publishing House, Cape Town.

Thexton, J.D., 2014, Neighbor-love from a margin: A pastoral theological construction employing class analysis, Ph.D. thesis, Texas Christian University, Fort Worth, TX.

Ujamaa, 2014, Doing contextual Bible study: A resource manual, s.n., Pietermaritzburg.

Vika, G.M., 2008, 'From maintenance to mission: A turning point in the history of methodism in southern Africa', in W. Bentley \& D.A. Forster (eds.), Methodism in Southern Africa, pp. 58-69, AcadSA Publishing, Kempton Park. 